\title{
Analisis Manfaat Rasio Keuangan Bank Untuk Memprediksi Perubahan Laba Dimasa Akan Datang Pada Bank Pembangunan Daerah Di Indonesia
}

\author{
IRFAN TANJUNG \\ Sekolah Tinggi Ilmu Ekonomi Bangkinang \\ Jl. A. Rahman Saleh No. 54A Bangkinang Kota \\ E-mail : fathurrahmanalbarr@gmail.com
}

\begin{abstract}
The ratio analysis can assist financial statement user in assessing the condition of company's finance, guiding creditor and investor in making decision, assessing management performance, as evaluation is things required to do the fore, checking risk and opportunity in the future. This research is to analyse empirically regarding financial statement is based on financial bank ratio. Have the benefit of financial bank ratio to prediction profit change in the future. There are 10 financial bank ratio of examine in the prediction of profit change as indenpendent variable. That are CAR, ATTM, APB, PPAPAP, Gross NPL, ROA, ROE, NIM, BOPO, and LDR. The Prediction of profit as dependent variable. The Data in this research are the ratios 26 BPD in all Indonesia reported in the ending year 2005 and 2006. The Discriminant Analysis of Statistical methods used to analyse the benefit of financial bank ratio in prediction of profit change. Enter Independents Together Method used to test hypothesis in sumultanly. The Result of Research indicate that financial ratio have benefit as profit predictor in the future. Financial Ratio which is significant it play a part in profit predictor in the future is Penyisihan Penghapusan Aktiva Produktif terhadap Aktiva Produktif with value mount classification equal to $88.5 \%$. But, the other financial ratios in this research no advantage as profit predictor in the future.
\end{abstract}

Keywords: CAR, ATTM, APB, PPAPAP, Gross GNP, ROA, ROE, NIM, BOPO, LDR, and Prediction of profit

Laporan keuangan menunjukan apa yang telah dilakukan manajemen atau pertanggungjawaban manajemen atas sumber daya yang dipercayakan kepadanya. Tujuan laporan keuangan adalah menyediakan informasi yang menyangkut posisi keuangan, kinerja, serta perubahan posisi keuangan suatu perusahaan yang bermanfaat bagi sejumlah besar pengguna dalam pengambilan keputusan ekonomi. Informasi kinerja bermanfaat untuk memprediksi kapasitas perusahaan dalam menghasilkan arus kas dari sumberdaya yang ada. Informasi tersebut juga berguna dalam perumusan pertimbangan tentang efektivitas perusahaan dalam memanfaatkan sumber daya (PSAK, 2009). Rasio adalah angka yang menunjukan hubungan antara satu unsur dengan unsur lainnya dalam laporan keuangan yang dinyatakan dalam bentuk matematis sederhana (Jumingan, 2005).
Analisis rasio dapat membantu pemakai laporan keuangan dalam menilai kondisi keuangan perusahaan, tidak terkecuali perusahaan perbankan. Pengukuran dan hubungan satu pos dengan pos lain dalam laporan keuangan yang tampak dalam rasio keuangan dapat memberikan kesimpulan berarti dalam penentuan tingkat kesehatan keuangan perusahaan. Analisis rasio juga dapat membimbing investor dan kreditor dalam membuat keputusan atau pertimbangan tentang pencapaian perusahaan dan prospek di masa datang. Analisis rasio digunakan untuk menilai kinerja manajemen dalam suatu periode apakah mencapai target seperti yang telah ditetapkan dan menilai kemampuan manajemen dalam memberdayakan sumberdaya perusahaan secara efektif serta dijadikan sebagai evaluasi hal-hal yang perlu dilakukan kedepan agar kinerja manajemen dapat 
ditingkatkan atau dipertahankan (Kasmir, 2008). Analisis rasio keuangan juga dimaksudkan untuk menilai risiko dan peluang di masa yang akan datang.

Kinerja keuangan dapat dilihat dari rasio rentabilitasnya, yaitu menunjukan kemampuan modal yang dipergunakan untuk menghasilkan laba. Laba diperlukan untuk kelangsungan hidup perusahaan dipakai sebagai ukuran prestasi yang dijadikan dasar untuk pengambilan keputusan investasi dan prediksi untuk meramalkan perubahan laba akan datang. Laba sering kali digunakan sebagai ukuran kinerja keuangan atau sebagai dasar bagi ukuran yang lain, seperti imbal hasil investasi atau laba per saham (PSAK, 2009). Bagi nasabah bank, kinerja keuangan adalah untuk menilai baik atau buruk tentang kondisi keuangan bank. Sedangkan bagi pihak manajemen kinerja keuangan sebagai alat untuk penyusunan rencana, target, anggaran, koordinasi dan evaluasi pelaksanaan operasi bank serta untuk pengambilan keputusan investasi.

Bank-bank di Indonesia dalam penyusunan laporan keuangannya termasuk rasio yang dibuatnya haruslah berpedoman pada peraturan Bank Indonesia yang disusun oleh Ikatan Akuntan Indonesia yang tergambar dalam Standar Khusus Akuntansi Perbankan Indonesia (SKAPI) dan Pedoman Akuntansi Perbankan Indonesia (PAPI). Rasio yang digunakan biasanya adalah rasio CAMEL (Capital, Asset, Management, Equity, dan Liquidity). Pemilihan Bank Pembangunan Daerah (BPD) sebagai obyek penelitian adalah karena penelitian pada perbankan khususnya pada Bamk Pembangunan Daerah menurut penulis ketahui juga belum banyak yang melakukannya.

Untuk itu penulis akan melakukan penelitian dengan judul: "Analisis Manfaat Rasio Keuangan Bank Untuk Memprediksi Perubahan Laba Masa Akan Datang Pada Bank Pembangunan Daerah di Indonesia

Bank adalah badan usaha yang menghimpun dana dari masyarakat dalam bentuk simpanan dan menyalurkannya kepada masyarakat dalam bentuk kredit dan atau bentuk bentuk lainnya dalam rangka meningkatkan taraf hidup rakyat banyak.

Perbankan menurut PSAK No.31 Tahun 2009 adalah lembaga yang berperan sebagai perantara keuangan (financial intermediary) antara pihak yang memiliki dana dan pihak yang memerlukan dana, serta sebagai lembaga yang berfungsi memperlancar lalu lintas pembayaran. Sedangkan menurut Undang-Undang Perbankan No.10 Tahun 1998 Perbankan adalah segala sesuatu yang menyangkut tentang bank, mencakup kelembagaan, kegiatan usaha, serta cara dan proses dalam melaksanakan kegiatan usahanya.

Pengertian menghimpun dana menurut Kasmir (2008), maksudnya adalah mengumpulkan atau mencari dana dengan cara membeli dari masyarakat luas dalam bentuk simpanan giro, tabungan dan deposito. Mengumpulkan atau menghimpun dana ini sering disebut dengan funding. Strategi bank dalam menghimpun dana adalah dengan memberikan rangsangan berupa balas jasa yang menarik dan menguntungkan berupa bunga atau bagi hasil bagi bank yang berdasarkan prinsif syariah. Kemudian rangsangan lainnya dapat berupa cendera mata, hadiah, pelayanan atau balas jasa lainnya. Menyalurkan dana dalam bentuk pinjaman atau kredit dan pembiayaan bagi bank yang berdasarkan prinsif syariah. Kegiatan ini dikenal dengan istilah lending

Menurut PSAK Tahun 2009 dinyatakan tujuan laporan keuangan adalah menyediakan informasi yang menyangkut keuangan, kinerja serta perubahan posisi keuangan suatu perusahaan yang bermampaat atau berguna bagi sejumlah pemakai dalam pengambilan keputusan ekonomi. Sedangkan dalam Pedoman Akuntansi Perbankan Indonesia Tahun 2008, menyatakan bahwa tujuan laporan keuangan adalah untuk memberikan 
informasi tentang posisi keuangan, kinerja, perubahan ekuitas, arus kas dan informasi lainnya yang bermanfaat bagi pengguna laporan dalam rangka membuat keputusan ekonomi serta menunjukkan pertanggungjawaban manajemen atas penggunaan sumber daya yang dipercayakan kepada mereka.

Laporan keuangan juga menunjukan apa yang telah dilakukan manajemen atau pertanggungjawaban manajemen atas sumber daya yang dipercayakan kepadanya. Sebagai pertanggungjawaban, laporan keuangan wajib disampaikan kepada pemilik. Namun dengan semakin besar keterlibatan pihak lain, maka laporan keuangan menjadi bagian penting informasi kepada pihak lain non pemilik, seperti kreditur, pemerintah, karyawan, dan sebagainya. Laporan keuangan juga dapat menurunkan informasi asimetri yaitu kondisi dimana informasi yang dimiliki oleh satu pihak lebih banyak dibandingkan dengan pihak lainnya. Informasi tentang perusahaan yang dimiliki oleh pemilik (investor/kreditur), sehingga dengan adanya laporan keuangan, informasi akan tersebar secara merata antara pengelola dengan pemilik perusahaan. Informasi dalam laporan keuangan dapat menurunkan perbedaan informasi dengan menurunkan: (a) adverse selection, dengan cara memindahkan informasi privat yang dimiliki oleh manajer menjadi informasi publik. Adverse Selection adalah ketidakyakinan para manajer atau pemilik karena salah satu pihak memiliki informasi yang lebih banyak dari lainnya, sehingga menguntungkan pihak tertentu: (b) moral hazard, yang dilakukan oleh manajer, karena perilaku manajer dapat dilihat dari pengaruhnya pada laba perusahaan atau asset perusahaan. Moral hazard adalah sikap tidak melaksanakan apa yang seharusnya dilaksanakan atau tidak melaksanakan kondisi ideal. Bank sebagai pemberi kredit biasanya menentukan debt covenant atau perjanjian hutang. Untuk melihat apakah bank memenuhi perjanjian kredit atau tidak dapat dilihat dari laporan keuangan. Posisi keuangan dipengaruhi oleh sumber daya yang dikendalikan, struktur keuangan, likuiditas, solvabilitas serta kemampuan beradaptasi terhadap lingkungan.

Pedoman Akuntansi Perbankan Indonesia Tahun 2008 mewajibkan Perbankan membuat laporan keuangan sebagai laporan kepada bank sentral dan pengguna lainnya yang menyangkut posisi keuangan, kinerja, perubahan posisi keuangan, dan catatan atas laporan keuangan seperti dicerminkan dalam laporan-laporan berikut ini :

a. Laporan Posisi Keuangan

b. Laporan Kinerja

c. Laporan Perubahan Posisi Keuangan

Informasi perubahan posisi keuangan bank, antara lain:

1) Perubahan kas dan setara kas

2) Perubahan ekuitas

Dalam PSAK No. 31 tahun 2009, menyatakan laporan keuangan bank terdiri dari:

a. Neraca

b. Laporan Laba Rugi

c. Laporan Arus Kas

d. Laporan Perubahan Ekuitas Catatan Atas Laporan Keuangan.

Menurut Horne dalam Kasmir (2008), adalah merupakan indeks yang menghubungkan dua angka akuntansi dan diperoleh dengan membagi satu angka dengan angka lainnya. Hasil rasio keuangan ini digunakan untuk menilai kinerja manajemen dalam suatu periode apakah mencapai target seperti yang telah ditetapkan. Kemudian juga dapat dinilai kemampuan manajemen dalam memberdayakan sumber daya perusahaan secara efektif. Analisis laporan keuangan khususnya memperhatikan pada penghitungan rasio keuangan agar dapat mengevaluasi keadaan pada masa lalu, sekarang dan proyeksi hasil di masa datang.

Menurut Scott, dkk (1999) dalam Warsidi dan Pramuka (2000) menyatakan bahwa Rasio keuangan dapat membantu 
kita mengidentifikasi beberapa kekuatan dan kelemahan keuangan perusahaan. Rasio keuangan memberikan dua cara untuk membuat perbandingan dari data keuangan perusahaan menjadi lebih berarti: (1) kita dapat meneliti rasio antar waktu untuk meneliti arah pergerakannya; dan (2) kita dapat membandingkan rasio keuangan perusahaan dengan perusahaan lain.

Untuk mengetahui kondisi keuangan suatu bank, maka dapat dilihat dari laporan keuangan yang disajikan oleh suatu bank pada suatu periode yang sekaligus mengambarkan kinerja keuangan bank selama periode tersebut. Agar laporan keuangan ini menjad berarti, maka perlu melakukan analisis terlebih dahulu. Analisis yang digunakan adalah dengan menggunkan rasio-rasio keuangan yang sesuai dengan standar berlaku (Kasmir, 2008).

menurut Kasmir, 2008 rasio keuangan bank disajikan hanya beberapa yang dianggap penting, seperti :
a. Rasio Likuiditas
b. Rasio Solvabilitas
c. Rasio Rentabilitas

Penghasilan (laba) seringkali digunakan perusahaan sebagai ukuran kinerja atau sebagai dasar bagi ukuran yang lain seperti imbalan investasi (return on investment) atau penghasilan per saham (PSAK, 2009). Prediksi laba merupakan peramalan mengenai hasil operasi perusahaan pada suatu periode tertentu. Prediksi laba dalam hal ini tidak menentukan nilai laba yang mungkin akan dihasilkan oleh perusahaan tapi lebih kepada suatu kenyataan bahwa laba perusahaan tersebut akan mengalami kenaikan atau mengalami penurunan (Sitorus, 2005).

Suhardito, $d k k$ (2000) dalam Sitorus, (2005), menyatakan bahwa prediksi laba merupakan suatu peramalan, karena itu tidak seorangpun yang dapat mengetahui secara pasti berapakah hasil operasi dan keuangan dari suatu perusahaan di masa depan dan banyaknya unsur ketidakpastian di masa depan, banyak penekanan dan evaluasi pada prestasi masa lalu dan masa kini sebagai indikator untuk masa depan, maka salah satu pendekatan yang menarik untuk dilakukan adalah memprediksi apakah suatu perusahaan akan mengalami kegagalan atau kesuksesan.

Prediksi atas laporan keuangan perusahaan merupakan informasi yang memberikan indikasi atas prospek hasil usaha dan keadaan keuangan di masa mendatang. Selain itu prediksi akan lebih mudah dibaca oleh investor, dibandingkan dengan laporan keuangan yang biasanya hanya bisa dibaca oleh akuntan. Prediksi atau ramalan adalah salah satu aspek sebelum perencanaan dan berguna untuk mengurangi ketidakpastian, jadi prediksi sangatlah penting bagi lingkungan dunia usaha, dimana sangat banyak unsur ketidakpastian, serta banyaknya unsur yang terlibat seperti stockholder, pemerintah dan stackeholder (Madjid, SNA IV)

Untuk mengevaluasi keuangan dan perubahan laba perusahaan, analis keuangan dan pemakai laporan keuangan harus melakukan analisis terhadap kesehatan perusahaan. Alat yang biasa digunakan adalah rasio keuangan. Evaluasi rasio akan memberikan hasil yang terbaik jika digunakan dalam suatu kombinasi untuk menunjuk suatu perubahan kondisi keuangan atau kinerja operasional selama periode tertentu, lebih lanjut dapat memberikan gambaran trend dan pola perubahan yang akhirnya akan memberikan indikasi adanya resiko dan peluang bisnis. (Kuncoro dan Suhardjono, 2002).

Di Indonesia, penggunaan rasio untuk mengevaluasi kinerja perusahaan diatur oleh pemerintah bagi perusahaan milik pemerintah. Untuk perusahaan swasta harus juga mengikuti peraturan ini dengan melaporkan rasio keuangan yang sama sebagai informasi tambahan diluar laporan keuangan inti (Machfoedz , 1994). Rasio keuangan merupakan perangkat analisis laporan keuangan yang 
paling populer dan paling sering digunakan. Suatu rasio menunjukkan hubungan matematis antara suatu data keuangan dengan data keuangan lainnya. Rasio keuangan seperti halnya alat-alat analisis yang lain adalah future oriented, oleh karena itu penganalisis harus mampu untuk menyesuaikan faktor-faktor yang ada pada periode waktu ini dengan faktorfaktor di masa yang akan datang yang mungkin akan mempengaruhi posisi keuangan atau hasil operasi perusahaan yang bersangkutan.

Helfert (1991) dalam Warsidi dan Pramuka (2000), analisis rasio keuangan merupakan instrumen analisis prestasi perusahaan yang menjelaskan berbagai hubungan dan indikator keuangan, yang ditujukan untuk menunjukkan perubahan kondisi keuangan atau prestasi operasi di masa lalu dan membantu menggambarkan trend pola perubahan tersebut, untuk kemudian menunjukkan resiko dan peluang yang melekat pada perusahaan yang bersangkutan. Makna dan kegunaan rasio keuangan dalam praktek bisnis pada kenyataannya bersifat subjektif tergantung kepada untuk apa suatu analisis dilakukan dan dalam konteks apa analisis tersebut diaplikasikan.

Secara individual rasio keuangan kecil artinya, kecuali jika dibandingkan dengan rasio standar yang layak dijadikan dasar pembanding. Apabila tidak ada standar yang dipakai sebagai dasar pembanding, dari penafsiran rasio-rasio suatu perusahaan, penganalisis tidak dapat menyimpulkan apakah rasio-rasio itu menunjukan kondisi yang menguntungkan atau tidak menguntungkan (Jumingan, 2005). Barnes (1987) dalam Machfoedz (1994), pencatatan mengenai rasio keuangan selalu digunakan untuk memprediksi baik secara implisit manapun secara ekplisit. adalah :

Hipotesis dalam penelitian ini

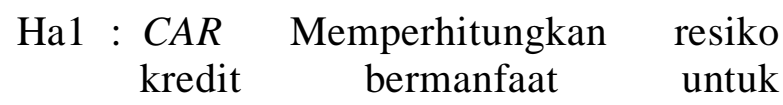

memprediksi laba masa akan datang pada Bank Pembangunan Daerah.

Ha2 : Rasio Aktiva Terhadap Modal bermanfaat untuk memprediksi laba masa akan datang pada Bank Pembangunan Daerah.

Ha3 : Rasio Aktiva Produktif bermasalah bermanfaat untuk memprediksi laba masa akan datang pada Bank Pembangunan Daerah.

Ha4 : Rasio Penyisihan Penghapusan Aktiva Produktif terhadap Aktiva Produktif bermanfaat untuk memprediksi laba masa akan datang pada Bank Pembangunan Daerah.

Ha5 : Rasio Non Perfoming Loan (NPL) bermanfaat untuk memprediksi laba masa akan datang pada Bank Pembangunan Daerah.

Ha6 : Rasio Return On Asset (ROA) bermanfaat untuk memprediksi laba masa akan datang pada Bank Pembangunan Daerah.

Ha7 : Rasio Return On Equity (ROE) bermanfaat untuk memprediksi laba masa akan datang pada Bank Pembangunan Daerah.

$\mathrm{Ha} 8$ : Net Income Margin (NIM) bermanfaat untuk memprediksi laba masa akan datang pada Bank Pembangunan Daerah.

Ha9 : Rasio Biaya Operasional Pendapatan Operasional bermanfaat untuk memprediksi laba masa akan datang pada Bank Pembangunan Daerah.

Ha10: Loans Debt Ratio (LDR) bermanfaat untuk memprediksi laba masa akan datang pada Bank Pembangunan Daerah.

\section{METODE}

Penelitian ini Menganalisis Manfaat Rasio Keuangan Bank Untuk Memprediksi Perubahan Laba Masa Akan Datang Pada Bank Pembangunan Daerah Di Indonesia, maka dari itu model penelitian ini adalah sebagai berikut : 
Populasi dalam penelitian ini adalah Bank Pembangunan Daerah di seluruh Indonesia sebanyak 26 buah Bank. Dan dalam penelitian ini tidak ada sampel karena seluruh populasi diambil. Obyek penelitian ini adalah laporan keuangan Bank Pembangunan Daerah untuk periode tiga tahunan (2004 - 2006).

Analisis yang digunakan dalam penelitian ini adalah Analisis Diskriminan Analisis Diskriminan adalah teknik multivariat yang termasuk pada dependence method dengan ciri adanya variabel dependen dan independen. Data variabel dependen berupa data kategori, sedangkan variabel independen data berupa data rasio (Singgih Santoso 2010). Analisis Diskriminan untuk menguji apakah probabilitas terjadinya variabel dependen dapat diprediksi dengan variabel independen (Ghozali, 2002). Analisis deskriptif digunakan untuk mengetahui gambaran dari variabel-variabel penelitian yang dapat dilihat dari mean, standard deviasi, variance, maximum, minimum, sum, range, kurtosis dan skewness (Singgih Santoso 2008).

Kombinasi linear untuk analisis diskriminan, juga dikenal sebagai fungsi diskriminan adalah :

$$
Z_{C u}=a+W_{1} X_{1 k}+W_{2} X_{2 k}+\ldots .+W_{n} X_{n k}
$$

Dimana:

$\mathrm{Z}_{\mathbf{C u}}=$ diskriminan $\mathrm{Z}$ skor dari fungsi diskriminan $\mathrm{C}$ untuk obyek $\mathrm{u}$

$\mathrm{a}=$ intercept

$\mathrm{Wn}=$ bobot diskriminan untuk variabel independen $\mathrm{n}$

$\mathrm{Xnk}=\quad$ variabel independen $\mathrm{n}$ untuk obyek $\mathrm{k}$

\section{HASIL}

Statistik deskriptif bertujuan untuk memberikan gambaran atau deskripsi suatu data yang dilihat dari minimum, maksimum, rata-rata, standar deviasi, varian, skewness dan kurtosis. Data akan diolah menggunakan SPSS. Data tersebut berisi 26 pengamatan pada 10 variabel rasio.

Tabel 1 : Statistik Deskriptif

\begin{tabular}{|l|l|l|l|l|l|l|}
\hline & $\mathrm{N}$ & Min & Max & Mean & $\begin{array}{l}\text { Std. } \\
\text { Deviation }\end{array}$ & Variance \\
\hline CAR & 26 & 10.29 & 38.94 & 20.1688 & 5.94664 & 35.362 \\
\hline ATM & 26 & 12.34 & 64.38 & 30.9850 & 12.29522 & 151.172 \\
APBermasalah & 26 & .27 & 6.00 & 1.4731 & 1.35272 & 1.830 \\
\hline PPAPAP & 26 & .51 & 4.55 & 1.6265 & .75698 & .573 \\
\hline GNPL & 26 & .45 & 14.00 & 2.9185 & 2.77188 & 7.683 \\
\hline ROA & 26 & .97 & 6.56 & 3.4927 & 1.43898 & 2.071 \\
ROE & 26 & 5.57 & 43.17 & 25.6831 & 8.85151 & 78.349 \\
\hline NIM & 26 & 6.27 & 17.31 & 10.7938 & 3.05629 & 9.341 \\
\hline BOPO & 26 & 56.27 & 94.41 & 74.4631 & 8.95045 & 80.111 \\
\hline LDR & 26 & 19.94 & 101.43 & 56.2723 & 23.24207 & 540.194 \\
Valid N (listwise) & 26 & & & & & \\
\hline
\end{tabular}

Dari output SPSS Statistik Deskriptif diatas terlihat nilai terendah, tertinggi, rata-rata, simpangan baku dan varian dari 26 Bank BPD di seluruh Indonesia dengan 10 rasio keuangan bank. Capital Adequacy Ratio memperhitungkan resiko kredit dengan nilai terendah 10.29 , tertinggi 38.94, rata-rata 20.1688, simpangan baku 5.94664 dan varian 35.362. Rasio Aktiva Tetap Terhadap Modal dengan nilai terendah 12.34, tertinggi 64.38, rata-rata 30.9850, simpangan baku 12.29522 dan varian 151.172. Rasio Aktiva Produktif Bermasalah dengan nilai terendah 0.27, tertinggi 6.00 , rata-rata 1.4731 , simpangan baku 1.35272 dan varian 1.830. Rasio Penyisihan Penghapusan Aktiva Produktif terhadap Aktiva Produktif dengan nilai terendah 0.51 , tertinggi 4.55 , rata-rata 1.6265, simpangan baku 0.75698 dan varian 0.573. Rasio Gross Non Performing Loans dengan nilai terendah 0.45 , tertinggi 14.0, rata-rata 2.9185 , simpangan baku 2.77188 dan varian 7.683. Rasio Return On Assets dengan nilai terendah 0.97 , tertinggi 6.56, rata-rata 3.4927 , simpangan baku 1.43898 dan varian 2.701. Rasio Return On Equity dengan nilai terendah 5.57, tertinggi 43.17 , rata-rata 25.6831 , simpangan baku 8.85151 dan varian 78.349. Rasio Net Income Margin dengan nilai terendah 6.27, tertinggi 17.31, rata-rata 10.7938, simpangan baku 3.05629 dan varian 9.341. Rasio Biaya Operasional Pendapatan Operasional dengan nilai terendah 56.27, tertinggi 94.41, rata-rata 74.4673 , simpangan baku 8.95045 dan varian 80.111 
dan Liquidity Debt Ratio dengan nilai terendah 19.94, tertinggi 101.43 , rata-rata 56.2723, simpangan baku 23.24207 dan varian 540.194.

Uji ini digunakan untuk mengetahui apakah data yang akan dianalisis berdistribusi normal atau tidak berdistribusi normal. Hal ini penting untuk mengetahui apakah analisis selanjutnya dalam penelitian ini menggunakan Analisis Diskriminan atau Regresi Logistik karena penyimpangan dari asumsi normalitas multivariate akan mempengaruhi signifikansi uji statistik dan tingkat ketepatan atau keakuratan klasifikasi. Kriteria pengujian dari test of normality ini adalah jika angka signifikansi ( sig ) > 0,05 maka data berdistribusi normal dan jika angka signifikansi ( sig ) $<0,05$ maka data tidak berdistribusi normal.

Tabel 2.: Uji Normalitas One-Sample Kolmogorov-Smirnov Test

\begin{tabular}{|c|c|c|c|c|c|c|c|c|c|c|}
\hline & CAR & ATM & $\begin{array}{l}\text { AP } \\
\text { Berm } \\
\text { a } \\
\text { salah }\end{array}$ & $\begin{array}{l}\text { PPAP } \\
\text { AP }\end{array}$ & NPL & ROA & ROE & NIM & BOPO & LDR \\
\hline $\mathrm{N}$ & 26 & 26 & 26 & 26 & 26 & 26 & 26 & 26 & 26 & 26 \\
\hline $\begin{array}{ll}\text { Norma } & \text { Mea } \\
1 & n\end{array}$ & $\begin{array}{l}20.168 \\
8\end{array}$ & 30.9850 & $\begin{array}{l}1.473 \\
1\end{array}$ & $\begin{array}{l}1.626 \\
5\end{array}$ & 2.9185 & 3.4927 & $\begin{array}{l}25.683 \\
1\end{array}$ & $\begin{array}{l}10.793 \\
8\end{array}$ & $\begin{array}{l}74.463 \\
1\end{array}$ & $\begin{array}{l}56.272 \\
3\end{array}$ \\
\hline $\begin{array}{ll}\text { Param } & \text { Std. } \\
\text { eters }^{\mathrm{a},} & \text { Devi } \\
\text { b } & \text { Detion }\end{array}$ & $\begin{array}{l}5.9466 \\
4\end{array}$ & $\begin{array}{l}12.2952 \\
2\end{array}$ & $\begin{array}{l}1.352 \\
72\end{array}$ & $\begin{array}{l}.7569 \\
8\end{array}$ & $\begin{array}{l}2.7718 \\
8\end{array}$ & $\begin{array}{l}1.4389 \\
8\end{array}$ & $\begin{array}{l}8.8515 \\
1\end{array}$ & $\begin{array}{l}3.0562 \\
9\end{array}$ & $\begin{array}{l}8.9504 \\
5\end{array}$ & $\begin{array}{l}23.242 \\
07\end{array}$ \\
\hline $\begin{array}{ll}\text { Most } & \text { Abso } \\
\text { Extre } & \text { lute }\end{array}$ & .141 & .100 & .211 & .207 & .187 & .105 & .097 & .087 & .138 & .107 \\
\hline $\begin{array}{ll}\text { me } & \text { Posit } \\
\text { Differ } & \text { ive }\end{array}$ & .141 & .100 & .211 & .207 & .175 & .105 & .094 & .087 & .138 & .107 \\
\hline $\begin{array}{l}\text { Nega } \\
\text { tive }\end{array}$ & -.101 & -.080 & -.187 & -.133 & -.187 & -.103 & -.097 & -.078 & -.103 & -.066 \\
\hline $\begin{array}{l}\text { Kolmogorov } \\
\text {-Smirnov Z }\end{array}$ & .718 & .508 & 1.077 & 1.053 & .951 & .536 & .493 & .445 & .701 & .547 \\
\hline $\begin{array}{l}\text { Asymp. Sig. } \\
\text { (2-tailed) }\end{array}$ & .680 & .959 & .197 & .217 & .326 & .937 & .968 & .989 & .709 & .926 \\
\hline
\end{tabular}

a. Test distribution is Normal.

\begin{tabular}{|c|c|c|c|c|}
\hline $\begin{array}{l}\text { Hasil } \\
\text { Hipotesis }\end{array}$ & $\begin{array}{l}\text { Kelaya } \\
\text { kan } \\
\text { Model }\end{array}$ & $\begin{array}{l}\text { Kecendrung } \\
\text { an Model }\end{array}$ & $\begin{array}{l}\text { Signifikan } \\
\text { si Good } \\
\text { of Fit Test }\end{array}$ & $\begin{array}{l}\text { Hipote } \\
\text { sa Nol } \\
\text { (Ho) }\end{array}$ \\
\hline \begin{tabular}{l}
\multicolumn{3}{l}{ Pertama: } \\
CAR Memperhitungkan \\
resiko Kredit tidak \\
bermanfaat untuk \\
memprediksi laba di \\
masa yang akan datang
\end{tabular} & $\begin{array}{l}\text { Model } \\
\text { memb } \\
\text { aik }\end{array}$ & $\begin{array}{l}0.994>0.05 \\
\text { Model } \\
\text { cenderung } \\
\text { sama }\end{array}$ & $\begin{array}{l}0.419> \\
0.05 \\
\text { Tidak } \\
\text { signifikan }\end{array}$ & $\begin{array}{l}\text { Diteri } \\
\text { ma }\end{array}$ \\
\hline $\begin{array}{l}\text { Kedua: Aktiva Terhadap } \\
\text { Modal tidak bermanfaat } \\
\text { untuk memprediksi laba } \\
\text { di masa yang akan } \\
\text { datang }\end{array}$ & $\begin{array}{l}\text { Model } \\
\text { memb } \\
\text { aik }\end{array}$ & $\begin{array}{l}0.973>0.05 \\
\text { Model } \\
\text { cenderung } \\
\text { sama }\end{array}$ & $\begin{array}{l}0.456 \quad> \\
0.05 \text { tidak } \\
\text { signifikan }\end{array}$ & $\begin{array}{l}\text { Diteri } \\
\text { ma }\end{array}$ \\
\hline $\begin{array}{lr}\text { Ketiga: } \\
\text { Rasio Aktivar Produktif } \\
\text { Bermasalah r tidak } \\
\text { bermanfaat untuk } \\
\text { memprediksi laba di } \\
\text { masa yang akan datang } \\
\end{array}$ & $\begin{array}{l}\text { Model } \\
\text { memb } \\
\text { aik }\end{array}$ & $\begin{array}{l}0.903>0.05 \\
\text { Model } \\
\text { cenderung } \\
\text { sama }\end{array}$ & $\begin{array}{l}0.122> \\
0.05 \text { tidak } \\
\text { signifikan }\end{array}$ & $\begin{array}{l}\text { Diteri } \\
\text { ma }\end{array}$ \\
\hline $\begin{array}{lr}\text { Keempat: } & \text { Rasio } \\
\text { Penyisihan } & \text { Penghapusan } \\
\text { Aktiva } & \text { Produktif } \\
\text { terhadap r radtiva } \\
\text { Produktif } & \text { bermanfaat } \\
\text { untuk memprediksi laba } \\
\text { di masa yang akan } \\
\text { datang }\end{array}$ & $\begin{array}{l}\text { Model } \\
\text { memb } \\
\text { aik }\end{array}$ & $\begin{array}{l}0.755>0.05 \\
\text { Model } \\
\text { cenderung } \\
\text { sama }\end{array}$ & $\begin{array}{l}0.010< \\
0.05 \\
\text { signifikan }\end{array}$ & Ditolak \\
\hline $\begin{array}{l}\text { Kelima: Rasio Non } \\
\text { Performing Loans tidak } \\
\text { bermanfaat untuk } \\
\text { memprediksi laba di } \\
\text { masa yang akan datang }\end{array}$ & $\begin{array}{l}\text { Model } \\
\text { memb } \\
\text { aik }\end{array}$ & $\begin{array}{l}0.990>0.05 \\
\text { Model } \\
\text { cenderung } \\
\text { sama }\end{array}$ & $\begin{array}{l}0.635> \\
0.05 \text { tidak } \\
\text { signifikan }\end{array}$ & $\begin{array}{l}\text { Diteri } \\
\text { ma }\end{array}$ \\
\hline 1 & 2 & 3 & 4 & 5 \\
\hline $\begin{array}{lr}\text { Keenam: Rasio } & \text { Return } \\
\text { On Asset } & \text { tidak } \\
\text { bermanfaat untuk } \\
\text { memprediksi laba di } \\
\text { masa yang akan datang }\end{array}$ & $\begin{array}{l}\text { Model } \\
\text { memb } \\
\text { aik }\end{array}$ & $\begin{array}{l}0.947>0.05 \\
\text { Model } \\
\text { cenderung } \\
\text { sama }\end{array}$ & $\begin{array}{l}0.258> \\
0.05 \\
\text { Tidak } \\
\text { signifikan }\end{array}$ & $\begin{array}{l}\text { Diteri } \\
\text { ma }\end{array}$ \\
\hline $\begin{array}{l}\text { Ketujuh: Rasio Return } \\
\text { On Equity bermanfaat } \\
\text { untuk memprediksi laba } \\
\text { di masa yang akan } \\
\text { datang }\end{array}$ & $\begin{array}{l}\text { Model } \\
\text { memb } \\
\text { aik }\end{array}$ & $\begin{array}{l}0.833>0.05 \\
\text { Model } \\
\text { cenderung } \\
\text { sama }\end{array}$ & $\begin{array}{l}0.038< \\
0.05 \mathrm{~T} \\
\text { signifikan }\end{array}$ & Ditolak \\
\hline $\begin{array}{l}\text { Kedelapan: Rasio Net } \\
\text { Income Margin tidak } \\
\text { bermanfaat untuk } \\
\text { memprediksi laba di } \\
\text { masa yang akan datang }\end{array}$ & $\begin{array}{l}\text { Model } \\
\text { memb } \\
\text { aik }\end{array}$ & $\begin{array}{l}0.990>0.05 \\
\text { Model } \\
\text { cenderung } \\
\text { sama }\end{array}$ & $\begin{array}{l}0.619> \\
0.05 \\
\text { Tidak } \\
\text { signifikan }\end{array}$ & $\begin{array}{l}\text { Diteri } \\
\text { ma }\end{array}$ \\
\hline $\begin{array}{lr}\text { Kesembilan: } & \text { Rasio } \\
\text { Biaya } & \text { Operasional } \\
\text { terhadap } & \text { Pendapatan } \\
\text { Operasional } & \text { bermanfaat } \\
\text { untuk memprediksi laba } \\
\text { di masa yang akan } \\
\text { datang } & \\
\end{array}$ & $\begin{array}{l}\text { Model } \\
\text { memb } \\
\text { aik }\end{array}$ & $\begin{array}{l}0.845>0.05 \\
\text { Model } \\
\text { cenderung } \\
\text { sama }\end{array}$ & $\begin{array}{l}0.047< \\
0.05 \\
\text { signifikan }\end{array}$ & Ditolak \\
\hline $\begin{array}{l}\text { Kesepuluh: Loan to } \\
\text { Deposit Ratio tidak } \\
\text { bermanfaat untuk } \\
\text { memprediksi laba di } \\
\text { masa yang akan datang }\end{array}$ & $\begin{array}{l}\text { Model } \\
\text { memb } \\
\text { aik }\end{array}$ & $\begin{array}{l}0.994>0.05 \\
\text { Model } \\
\text { cenderung } \\
\text { sama }\end{array}$ & $\begin{array}{l}0.716> \\
0.05 \\
\text { Tidak } \\
\text { signifikan }\end{array}$ & $\begin{array}{l}\text { Diteri } \\
\text { ma }\end{array}$ \\
\hline
\end{tabular}

Kolmogorov-Smirnov terlihat bahwa semua variabel yang menunjukkan distribusi normal dimana nilainya > 0,05 tidak ada variabel yang tidak berdistribusi normal karena nilai signifikansinya $<0,05$. Berdasarkan tabel uji $\mathrm{K}-\mathrm{S}$ diatas, penulis menyimpulkan bahwa analisis dalam penelitian ini menggunakan analisis Discriminant Analysis, karena asumsi bahwa data berdistribusi normal.

\section{PEMBAHASAN}

Berdasarkan hasil pengujian variabel rasio secara bersamaan atau simultan diperoleh hasil sebagai berikut : Capital Adequacy Ratio (CAR) memperhitungkan resiko kredit tidak bermanfaat untuk memprediksi laba dimasa yang akan datang. Rasio Aktiva Tetap Terhadap Modal tidak bermanfaat untuk memprediksi laba dimasa yang akan datang. Rasio Aktiva Produktif Bermasalah tidak bermanfaat untuk memprediksi laba dimasa 
yang akan datang.

Rasio Penyisihan Penghapusan Aktiva Produktif terhadap Aktiva Produktif bermanfaat untuk memprediksi laba dimasa yang akan datang. Rasio Gross Non Performing Loans (GNPL) tidak bermanfaat untuk memprediksi laba dimasa yang akan datang. Rasio Return On Asset (ROA) tidak bermanfaat untuk memprediksi laba dimasa yang akan datang. Rasio Return On Equity $(R O E)$ bermanfaat untuk memprediksi laba dimasa yang akan datang.

Rasio Net Income Margin (NIM) tidak bermanfaat untuk memprediksi laba dimasa yang akan datang. Rasio Biaya Operasional terhadap Pendapatan Operasional bermanfaat untuk memprediksi laba dimasa yang akan dating. Loan Deposit Ratio (LDR) tidak bermanfaat untuk memprediksi penurunan laba dimasa yang akan datang.

Jadi dari 10 rasio keuangan yang diuji secara simultan diketahui bahwa rasio yang bermanfaat untuk memprediksi penurunan laba adalah Rasio Penyisihan Penghapusan Aktiva Produktif terhadap Aktiva Produktif. (PPAPAP ), Rasio Return On Equty, dan Rasio Biaya Operasional dan Pendapatan Operasional (BOPO), sedangkan ketujuh rasio lainya tidak bermanfaat untuk memprediksi perubahan laba dimasa akan dating. Dengan menggunakan metode StepWise Estimation diperoleh hasil analisis sebagai prediktor yang signifikan adalah variabel PPAPAP dengan tingkat signifikansi $<$ 0,05 yaitu 0,010 dan Chi-Square 6.597. Hanya variabel PPAPAP yang bisa dimasukan untuk dianalisa lebih lanjut pada metode stepwise, sedangkan kesembilan variabel lainnya tidak bisa dimasukan untuk dianalisis lebih lanjut. Hasil analisis dengan metode stepwise diperoleh persamaan fungsi discriminant analysis yaitu $\mathbf{Z}$ Score = $2.423+1.489$ PPAPAP.

Tingkat keakuratan/kebenaran dari prediksi rasio keuangan menggunakan analisis diskriminan pada penelitian ini hasilnya adalah sebsar $\mathbf{8 8 , 5 \%}$.

Jurnal Daya Saing (Vol. 5, No. 3 Okober 2019)

\section{SIMPULAN}

Hasil penelitian menunjukkan bahwa rasio keuangan bermanfaat sebagai prediktor laba di masa akan datang adalah rasio Penyisihan Penghapusan Aktiva Produktif terhadap Aktiva Produktif dengan nilai tingkat klasifikasi sebesar $88.5 \%$. Sedangkan rasio keuangan yang lainnya dalam penelitian ini tidak bermanfaat sebagai prediktor laba dimasa akan datang.

\section{DAFTAR RUJUKAN}

Jumingan, "Analisis Laporan Keuangan". PT. Bumi Aksara, Jakarta, 2005.

Kasmir, "Manajemen Perbankan". Rajawali Press, Jakarta, 2008.

Kasmir, “Analisis Laporan Keuangan”. Rajawali Press, Jakarta, 2008.

Kuncoro, M dan Suhardjono, "Manajemen Perbankan", Teori dan Aplikas. BPEE, Yogyakarta, 2002.

Laporan Keuangan Tahunan Bank Pembangunan Daerah Tahun 2004-2006, www.Asbanda.Com, (Mei 2009).

Machfoed, M, "Financial Ratio Analysis and The Prediction of Earning Changes in Indonesia”, 1994.

Peraturan Bank Indonesia Nomor 6/10/PBI/2004 tentang Sistem Penilaian Tingkat Kesehatan Bank Umum, www.bi.go.id, (12 April 2004).

Santoso, S, "Panduan Lengkap menguasai SPSS 16". PT. Elex Media Komputindo, Jakarta, 2008

Santoso, S, "Statistik Multivariat". PT. Elex Media Komputindo, Jakarta, 2010

Sori, Z.M dan Jalil, H.A, "Financial Ratios, Discriminant Analysis and the p.ISSN: 2407-800X e.ISSN: 2541-4356 
Prediction of Corporate Distress". Jurnal of Money, Investment and Banking, Http://www.Eurojournals.com/JMIB .htm, (9 Mei 2009).

Sitorus, M, "Perananan Rasio Keuangan Sebagai Salah Satu Alat Dalam Memprediksi Perubahan Laba Pada Bisnis dan Jasa Manufaktur”. 2005.

Warsidi dan Pramuka, B.A, ’Evaluasi Kegunaan Rasio Keuangan Dalam Memprediksi Perubahan Laba di Masa Yang Akan Datang: Suatu Studi Empiris Pada Perusahaan Yang Terdaftar di Bursa Efek Jakarta”. Jurnal Akuntansi dan Manajemen, 2000. 